An official publication of the International Society for Energy, Environment and Sustainability (ISEES)
Journal of Energy and
Environmental Sustainability
Journal homepage : www.jees.in

\title{
Second generation bioethanol production: Technical progress, possibilities and challenges
}

\author{
Sharon Mano Pappu J, Sathyanarayana N Gummadi * \\ Applied and Industrial Microbiology Laboratory, Bhupat and Jyoti Mehta School of Biosciences, Department of Biotechnology, \\ Indian Institute of Technology Madras, Chennai 600 036, India
}

\section{A R T I C L E I N F O}

Received : 15 September 2017

Revised : 05 November 2017

Accepted : 22 November 2017

Keywords:

$2 \mathrm{G}$ bioethanol, lignocellulose, ethanol

blending programme, fermentation,

saccharification

\begin{abstract}
A B S T R A C T
Energy consumption has increased steadily over the last century as the world population has grown and many countries have become more industrialized. Increase in energy demand and depletion of fossil reserves have motivated researchers toward the development of alternative fuels that are eco-friendly, renewable and economical. Production of ethanol by utilization of lignocellulosic biomass materials including agricultural and forest residues, herbaceous and woody crops have become capable alternatives that offer unique ecological and economic benefits. Bioethanol, a renewable, eco-friendly and sustainable liquid fuel is expected to have a promising future in confronting today's global energy crisis. Even though, production of bioethanol has been greatly improved by new technologies, there are still challenges that need to be investigated. Technical progress in the development of second generation bioethanol production, promises and challenges are explained. The prominence on developing an elementary understanding of the technology for biomass conversion to ethanol, reduction in production costs and strategies to accelerate commercialization are discussed.
\end{abstract}

(C) 2017 ISEES, All rights reserved

\section{Introduction}

In the $21^{\text {st }}$ century, one of the major challenges for society is to meet the increasing energy demand for industrial progressions and transportation. The continual use of fossil fuels to meet the world's increasing demand for energy is imperiled by increasing carbon dioxide concentration in the atmosphere and interests over global warming( $\mathrm{Yu}$ 2003; Demirbas et al. 2004). The combustion of fossil fuels such as oil and coal accounts for $73 \%$ of the $\mathrm{CO}_{2}$ production, which is a major cause of global warming(Lokhorst and Wildenborg 2005). It is of major concern to meet the forthcoming demand of energy with significant reduction of greenhouse gas (GHG) emissions. This problem can be resolved by implementing technologies built on different sources of energy. The issue of global warming and its awareness has led to intensive interest in developing alternate technologies to mitigate greenhouse gas emission(Lombardi 2003). The present attempt is to control the emission of GHG by focusing on developing alternate technologies that: (i) less consumption of energy, (ii) increase energy conversion efficiency (iii) reduce content of carbon in fuels, (iv) augment $\mathrm{CO}_{2}$ sinks. The amount of carbon dioxide produced and the pollutants level will be reduced as the use of fossil fuels reduced (Demirbas 2006). The exploration for sources of renewable energywhich reduce GHG emissions becomes a subject of prevalentconsideration as the dependence on usage of fossils as fuels grows.(Dias De Oliveira et al. 2005). To diminish the net influence of GHGs to the atmosphere, an alternative fuel must be readily available, feasible in technical terms, competitive and suitable in natural provisions.
Numerous alternative biofuels have been documented as a probable substitute to petroleum-derived transportation fuels (Govinda swamy and Vane 2007).

Biofuels which are derived from biomass has an edge over petroleum based fuels. Biofuels have great impact on environment and economy and the benefits of biofuels are listed in Table 1. Use of biofuels helps to mitigate GHG emissions, provides sustainable and clean energy source and reduce the dependency of developing countries on oil import when produced in large scale. Geologically, the biofuel sources are distributed consistently than conventional fossil fuels, which makes the energy source local and readily available; thus, provides a security of supply. The raw material can be produced with less energy and low input;thus, they are less expensive than conventional feedstock. Biofuels include bioethanol,biodiesel, vegetable oils,biomethanol,biogas and bio hydrogen Due to its sustainability, availability, renewability, provincial development, job opportunities and biodegradability, biofuels have gained vast consideration in countries all over the world (Hahn-Hägerdal et al. 2006). Bioethanol is considered as extensively used biofuel for transportation because of its blending property with gasoline.

\section{Bioethanol and its properties}

Bioethanol $\left(\mathrm{CH}_{3}-\mathrm{CH}_{2}-\mathrm{OH}\right)$, a biofuel that can be produced from different feedstocks. Bioethanol has cetane number and octane number 8 and 107 respectively, with auto-ignition temperature of $606 \mathrm{~K}$ and 26.7 $\mathrm{MJ} / \mathrm{Kg}$ of lower heating value. High octane number, broad limits of

\footnotetext{
* Corresponding Author: gummadi@iitm.ac.in
} 
Table 1. Major benefits of bioethanol - environmental and economic impact

\begin{tabular}{|l|l|l|}
\hline Economic impacts & Environmental impacts & Energy security \\
\hline Sustainability & Reduction of GHG emissions, air & Reliable supply, availability \\
Fuel diversity & pollution & Reduced usage of fossil fuel \\
Renewability \\
Increased number of rural manufacturing jobs & High efficiency of combustion, & \\
Increased investments in plant and equipment & Improved usage of land and water & \\
Agricultural development & Biodegradability & \\
Competitiveness & Sequestration of carbon & \\
Decreased dependency on imported petroleum & & \\
\hline
\end{tabular}

flammability, high flame speeds and highheat of vaporization makes bioethanol a suitable blender. These properties permit for a high compression ratio, short burn time and lean burn engine, which makes bioethanol as an efficient transportation fuel blender. Though it has many advantages over gasoline, its corrosiveness, low flame luminosity, lower vapor pressure and lower energy density than gasoline makes it as a blending fuel. For large scale production of bioethanol, cost is an important factor. The production of bioethanol from lignocellulosic wastes avoids the competition of food vs. fuel caused by first generation bioethanol production. It has been estimated that 117 billion gallons of bioethanol and 130 billion gallons of bioethanol can be produced from total crop residues and wasted crops per year. The amount of ethanol produced from the lignocellulose biomass is 16 times greater than the ethanol produced globally. Abundantly available lignocellulosic materials are renewable and low cost. Grasses, sawdust, woodchips and crop residues such aswheat straw, rice straw, corn straw and sugarcane bagasse can be employed as the raw material for bioethanol production. Henceforth production of bioethanol could be considered as the effective technology to utilize the agricultural wastes(Pereira et al. 2016).

Fig. 1 shows a bar graph comparing the annual consumption of gasoline, aviation fuel and diesel (in Billion litres) in India for the year 2008-2016 and estimation for the year 2017. It depicts that the consumption of transportation fuels in India is increasing every year, raising the demand for alternate fuels. The estimated annual consumption of transportation fuel in India is projected to be 140 billion litres for the year 2017. Motor gasoline demand has increased every year and the estimation reveals that the gasoline demand has almost increased by 1.7 times. There is a proportionate demand for blending ethanol. 5\% blending requires 1.11 billion litres by 2017 , whereas $10 \%$ blending requires 2.22 billion litres (Table 2). Global ethanol production in billion gallons across Europe, Brazil, USA and rest of the world for the year 2007-2016 was plotted in Fig. 2.The ethanol production in the rest of the world is only 490 million gallons. This clearly depicts the scenario of supply demand for ethanol in most of the countries apart from the major players mentioned in the graph (Fig. 2), therefore raising the necessity for large scale production of ethanol at an affordable price.

\section{Chemical composition of lignocellulose materials}

Around half of the world's biomass is comprised of lignocellulosic biomass and it was estimated to be produced about $10-50$ billion ton per year(Claassen et al. 1999). Potential lignocellulosic biomass for bioethanol production can be classified into six main groups: crop residues, hardwood, softwood, cellulose wastes, herbaceous biomass and municipal solid wastes
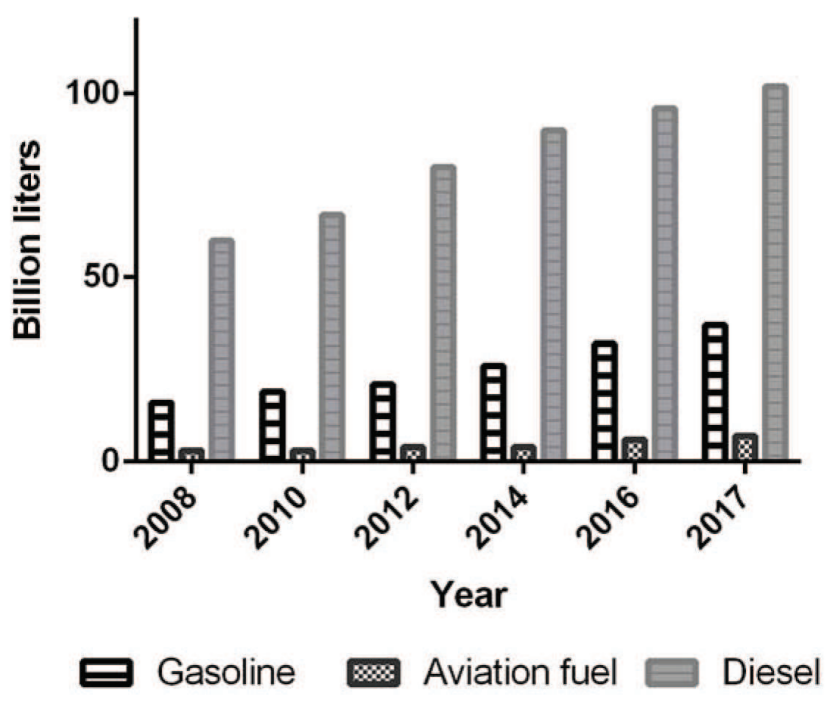

Reference: Petroleum Planning and Analysis Cell, Government of India (GOI), http://ppac.org.in/content/147_1_ConsumptionPetroleum.aspx

Figure 1 Comparison of annual consumption of gasoline, aviation fuel and diesel (in Billion litres) in India for the year 2008-2016 and estimation for the year 2017. The graph depicts that the consumption of transportation fuels in India is increasing every year, raising the demand for alternate fuels.

(MSW). The composition of some of the major crop residues used for bioethanol production is given in Table 3. Composition of lignocellulosic biomass in chemical terms is given in terms of weight $\%$ as follows: carbon $(\mathrm{C})-48 \%$, hydrogen $(\mathrm{H})-6 \%$ and oxygen $(\mathrm{O})-45 \%$, and minor component being the inorganic matter. Current, bioethanol production is mainly from agricultural wastes such as cane bagasse, straw of rice, wheat and corn(Pereira et al. 2015). When compared to other major crop residues, rice straw is the most copious and can possibly

Table 2.Projected ethanol demand for blending for the year 2017 based on previous requirement data

\begin{tabular}{|l|l|l|l|l|}
\hline \multirow{2}{*}{ Year } & \multicolumn{2}{|c|}{ Motor gasoline } & \multicolumn{2}{c|}{ Ethanol demand } \\
\cline { 2 - 5 } & $\begin{array}{l}\text { Consumption } \\
\text { (million gallons) }\end{array}$ & $\begin{array}{l}\text { Demand } \\
\text { (million gallons) }\end{array}$ & $\begin{array}{l}5 \% \text { blending } \\
\text { (million gallons) }\end{array}$ & $\begin{array}{l}10 \% \text { blending } \\
\text { (million gallons) }\end{array}$ \\
\hline 2006 & 2785 & 3380 & 170 & 340 \\
\hline 2007 & 3082 & 3740 & 190 & 370 \\
\hline 2008 & 3330 & 4640 & 200 & 400 \\
\hline 2017 & 4831 & 5860 & 300 & 596 \\
\hline
\end{tabular}

Reference: http://wds.iea.org/wds/pdf/WEDBES_Documentation.pdf 


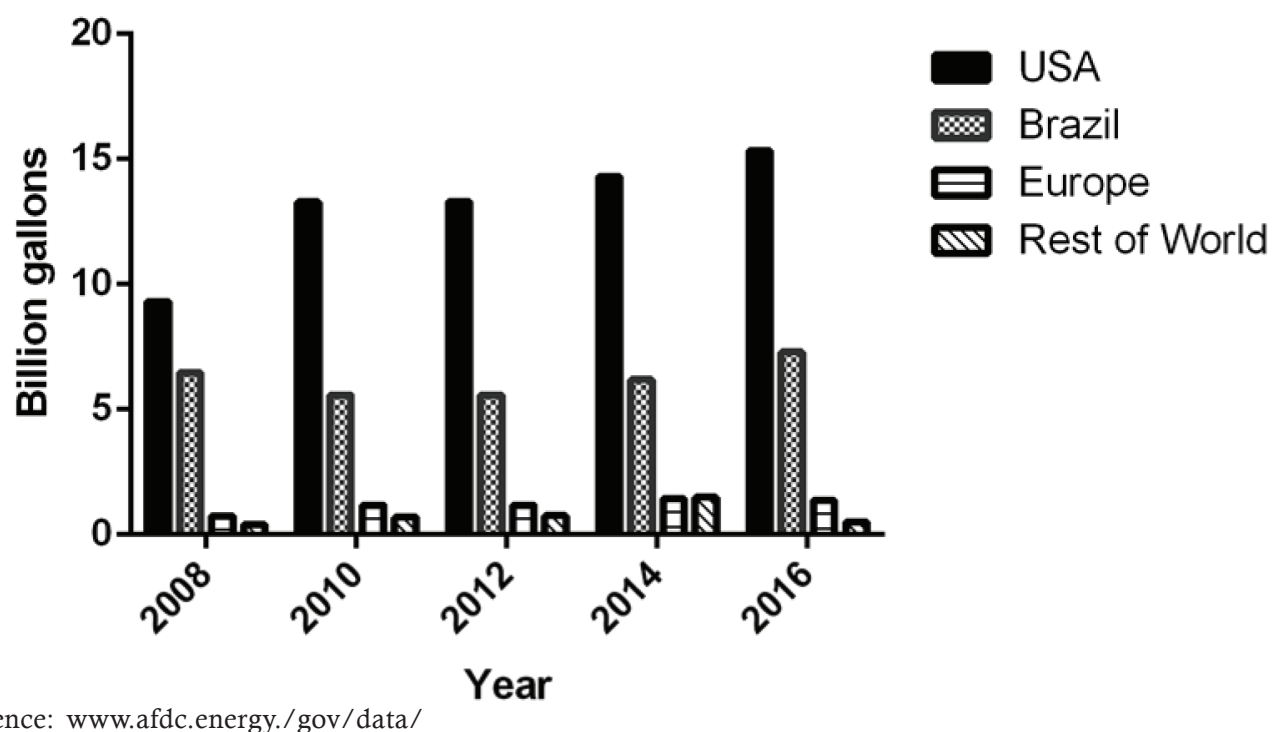

Figure 2 Global ethanol production in Billion gallons across USA, Brazil, Europe and rest of the world for the year 2007-2016.

Table 3. Chemical composition of lignocellulosic biomass

\begin{tabular}{|l|l|l|l|l|}
\hline Source & $\begin{array}{l}\text { Cellulose } \\
(\%)\end{array}$ & $\begin{array}{l}\text { Hemicellulose } \\
(\%)\end{array}$ & $\begin{array}{l}\text { Lignin } \\
(\%)\end{array}$ & $\begin{array}{l}\text { Ash } \\
(\%)\end{array}$ \\
\hline Rice straw & $32-47$ & $19-27$ & $5-24$ & 12.4 \\
\hline Wheat straw & $35-45$ & $20-30$ & $8-15$ & 10.1 \\
\hline Corn straw & 42.6 & 21.3 & 8.2 & 4.3 \\
\hline Bagasse & 65 & - & 18.4 & 2.4 \\
\hline
\end{tabular}

produce 54 billion gallons of bioethanol per annum, which is maximum among the four statedcrop residues(Saini et al. 2015).

A complex polymer of cellulose, hemicellulose and lignin constitutes lignocellulose. Cellulose is a linear homopolymer of repeating glucose units linked by $\beta 1,4$ glycosidic bonds and are crystalline in nature. Hemicellulose, second most abundant component, is a heteropolymer of $\mathrm{C} 5$ and $\mathrm{C} 6$ sugars such as D-xylose,D-glucose, D-arabinose,D-mannoseand
D-galactose and are highly branched. Lignin is tightly bound to cellulose and hemicellulose and hydrophobic in nature. Lignin, an aromatic polymer of p-hydroxyphenylpropanoid units and plays a protective role by preventing these two polymers from microbial attack (Sarkar et al. 2012).

Several research studies have been conducted throughout the world to develop large-scale bioethanol production from lignocellulosic biomass have been carried throughout the world. The major limiting factor is processing of feedstock due to its inherent complex nature. High complex nature and composition of lignocellulose biomass makes pre-treatment process difficult.In order to convert lignocellulose biomass to bioethanol or other products, cellulose and hemicellulose has to be broken down into simple fermentable sugars. Pre-treatment of lignocellulosic biomass is a complex and energy-consuming process.

\section{Production of bioethanol from lignocellulosic biomass}

Production process of bioethanol from lignocellulosic biomass consists of followingunit operations: pre-treatment, hydrolysis, detoxification, fermentation and product separation. Schematic flowsheet for the bioconversion of biomass to bioethanol is shown in Fig. 3. (Balat et al. 2008).

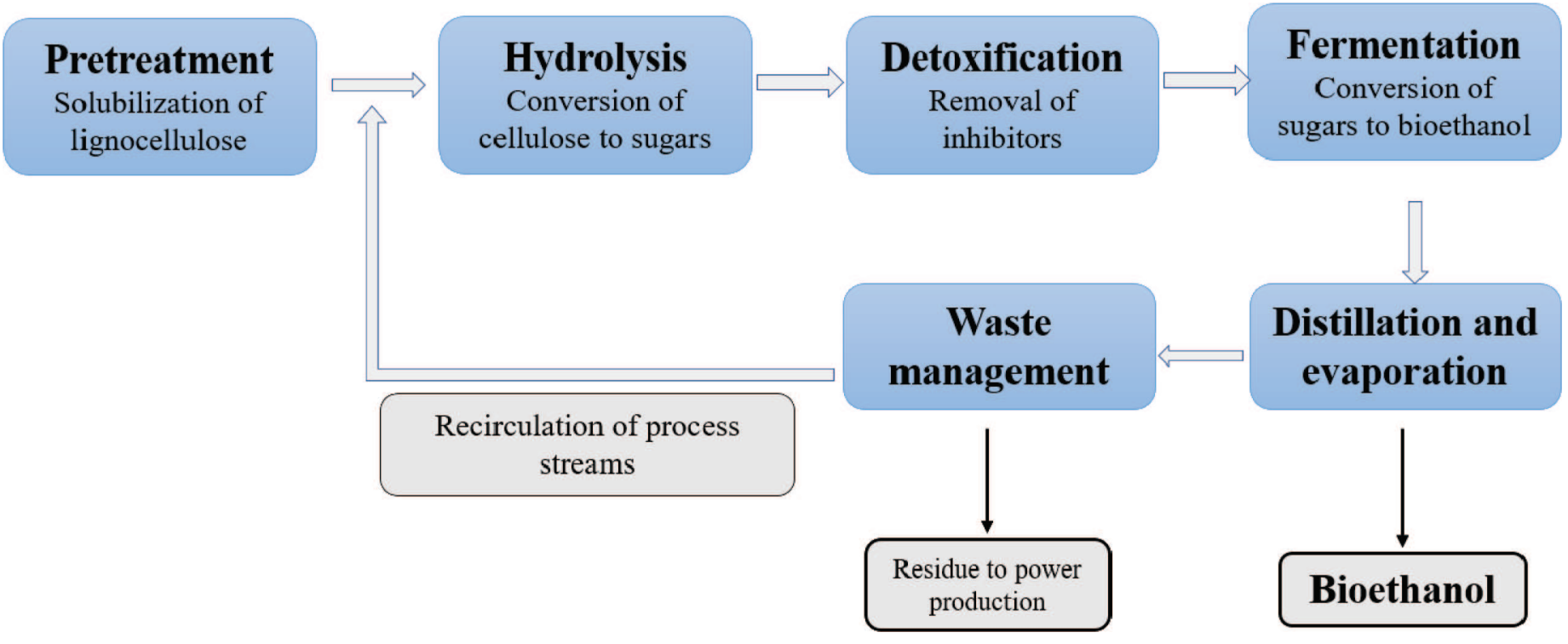

Figure 3 Flowchart depicting the major steps involved in Bioethanol production from lignocellulosic biomass 


\subsection{Pre-treatment of lignocellulosic biomass}

The foremostchallenge in the process of bioethanol production from lignocellulosic biomass is the feedstock pre-treatment. Lignocellulose biomass is a complex made up of a matrix of hemicellulose and cellulose and bound by lignin. Pre-treatment offers breakdown of lignocellulosic matrix in order to decrease the crystalline nature of cellulose and to intensify the segment of amorphous cellulose, the appropriate form for enzymatic process. In addition to increasing the fraction of amorphous cellulose, pre-treatment helps in hydrolysing main part of hemicellulose and degradation of lignin. The other factor that affects the hydrolysis of cellulose is the porosity of lignocellulosic materials. Lynd, 1996 showed that ethanol yield is less than $20 \%$ of theoretical yield without pre-treatment whereas the yield after pre-treatment of raw materials exceeds $90 \%$ of theoretical. Therefore, pre-treatment aims in intensifying the porosity of materials, to reduce the degree of crystallinity of cellulose, the removal of hemicellulose and lignin. Pre-treatment helps in improvement of sugar formation or tendency to form sugars during subsequent hydrolysis by enzyme, and to evade inhibitor formation. Numerous physical, chemical, physical-chemical and biological processes have been projected and advanced for the pre-treatment of feed stocks(Sun and Cheng 2002).

\subsubsection{Physical methods}

\subsubsection{Mechanical comminution}

Pretreatment of lignocellulosic biomass by mechanical comminution method results in reduced degree of polymerization of cellulose, decreased crystallinity and decreased particle size thereby increasing specific surface area in order to achieve high efficiency in cellulose conversion. After chipping, the biomass materials are reduced to $10-30 \mathrm{~mm}$ in size, whereas the biomasses are reduced to $0.2-2 \mathrm{~mm}$ by grinding or milling. When compared to conventional ball milling method, other milling methods, which include two-roll milling, hammer rolling, colloid milling and vibratory milling the digestibility of the lignocellulose materials, are improved. Due to high energy consumption for attaining specific biomass characteristics and particle size, this method is not economically feasible for scale -up (Talebnia et al. 2010).

\subsubsection{Mechanical extrusion}

Lignocellulosic biomass materials are exposed to temperature higher than $300^{\circ} \mathrm{C}$ followed by shearing and mixing. Extrusion is used to produce gaseous products and residual char that results in physical and chemical modifications of cellulose. Disruption of lignocellulosic biomass generating defibrillation, fibrillation and shortening of the fibers resulting in availability of carbohydrates for enzyme hydrolysis mainly due to the combined effect of shear mixing and high temperature. Improved efficiency of extrusion method will be achieved by considering different parameters of reactor(Pandey 2009). Pre-treatment of cellulose by mechanical methods increase reactivity during enzyme hydrolysis, but are not preferred due to high maintenance and capital costs involved(Ghosh and Ghose 2003).

\subsubsection{Microwave oven and electron beam irradiation treatment}

In aqueous environment, microwave generates thermal and nonthermal effects on lignocellulose. Microwave radiation causes internal heat generation in biomass due to the vibrations of polar bonds in the biomass and in the aqueous media. This results in explosion effect and enhances the disruption of recalcitrant lignocellulosic structures. The environment becomes acidic due to the release of acetic acid from lignocellulose by autohydrolysis( $\mathrm{Hu}$ and Wen 2008).

The vibration of polar bonds, disruption and shock to the bonds by electron beam irradiation accelerates biological, chemical and physical processes. Increase in surface area, reduction in degree of polymerization and crystalline nature of cellulose, hemicellulose hydrolysis and depolymerization of lignin were achieved by high energy radiation (Intanakul et al. 2003).

\subsubsection{Chemical methods}

Chemical pre-treatment employs chemical agents such as strong acids (Concentrated or dilute $\mathrm{HCl}$ and $\mathrm{H}_{2} \mathrm{SO}_{4}$ ), alkalis, organic solvents and ozone. Chemical method results in breakdown of lignin and destroys the link between lignin and cellulose/hemicellulose.(Sun and Cheng 2002).

\subsubsection{Alkali pretreatment}

The objective of alkali treatment is to increase the accessibility of enzyme to cellulose and hemicellulose by removing the lignin and other acid substitutions on hemicellulose. Pretreatment by alkali can be carried out at lower temperatures and pressures for hours or days. Alkali pretreatment of lignocellulosic biomass involves the use of bases such as sodium, calcium, potassium and ammonium hydroxide. Effectiveness of alkaline pre-treatment depends on the lignin content of the biomass.

Among these four hydroxides, pretreatment with $\mathrm{NaOH}$ has been studied extensively. Treatment of lignocellulose biomass with dilute $\mathrm{NaOH}$ results in swelling, decreasing degree of polymerization and crystallinity, linkage separation between cellulose and lignin, disruption of lignin structure and increased internal surface area(Pandey et al. 2000). Studies have shown that 3.92-fold increase in digestibility of hardwood and $55 \%$ to $20 \%$ reduction in lignin content after $\mathrm{NaOH}$ treatment but no effect on softwoods(Millett et a1. 1976). NaOH pretreatment showed increased saccharificaiton rates $-35.5 \%, 30.0 \%$ and $25.5 \%$ for bagasse, wheat and rice straw respectively.

Calcium hydroxide or lime is considered as efficient as other alkali in pretreatment of lignocellulose under appropriate conditions. Lime can be recovered from hydrolysate by reaction with $\mathrm{CO}_{2}$ results in the formation of carbonate and can be reconverted to lime. Pretreatment of lignocellulose with lime and air or oxygen at temperature ranges from $50^{\circ} \mathrm{C}$ to $100^{\circ} \mathrm{C}$ for hours to weeks. Pretreatment with lime has lower cost and requires less safety measurements (Sun et al. 1995).

\subsubsection{Acid pretreatment}

Acid pretreatment of lignocellulose biomass results in solubilization of hemicellulose fraction and to increase the accessibility of cellulose to enzymes. Concentrated or diluted acid can be employed in the acid treatment of biomass but concentrated acid treatment is less attractive due to the formation of compounds that are inhibitory to further hydrolysis(Mosier et al. 2005). Disadvantages of using concentrated acid for treatment methods include corrosion problems of equipment and acid recovery. Scaling up of this pretreatment method lost interest due to its high maintenance and operational cost (Cardona et al. 2010). On the other hand, treatment with diluted acid is more favorable for large scale applications. Dilute acid pretreatment can be carried out at high temperature (453 K) for a short time or at low temperature for long time (393 K). Dilute acid pre-treatment is accomplished in two-stages where hemicellulose components gets depolymerized when treated at temperature $140^{\circ} \mathrm{C}$ for $15 \mathrm{~min}$ is the first step, in order to circumvent generation of carboxylic acids and furan mixtures, trailed by treatment at $190^{\circ} \mathrm{C}$ for $10 \mathrm{~min}$ to make cellulose available for enzyme hydrolysis (Saha et al. 2005).

\subsubsection{Ozonolysis}

Increase in biodegradability of the cellulose and break down of hemicellulose and lignin can be achieved by treating lignocellulosic biomass using ozone gas. This pretreatment method has been widely applied to treat agricultural and forestry wastes to lessen the lignin content. The main advantage of ozonolysis pretreatment is its effectiveness in removing lignin without toxic by-product formation(Pandey 2009). Ozonolysis results in $49 \%$ break down of lignin in stalks of corn and $60 \%$ reduction of lignin in hemicellulose free stalks(Williams and Onwudili 2006). A study was conducted on wheat straw to test the effect of ozonolysis on yield of fermentable sugars in enzymatic hydrolysis process. Ozonated wheat straw results in $88.6 \%$ enzymatic hydrolysis yield when compared to non-ozonated wheat straw which yields only $29 \%$ (Kumar et al. 2009). This process is too expensive to be scaled up since it requires large amount of ozone.

\subsubsection{Organosolv}

Organic or aqueous solvent mixtures such as ethylene glycol, ethanol, methanol, acetone and tetrahydrofurfuryl alcohol to solubilize lignin and to enhance accessibility of cellulose for enzyme hydrolysis(Zhao et al. 2009). Advantage of pretreating lignocellulose with organic solvents is the recovery of pure lignin as a by-product. Pentose sugar (xylose) can be obtained when treated with mixture of solvents and acids. Organosolv treatment process has been proposed to be combined with other pretreatment methods such as acid pretreatment to separate hemicellulose and lignin. If acid catalysts are used, this can be run at lower temperatures however, addition of acid can be avoided to achieve complete delignification when operated at higher temperature. Appropriate separation and extraction techniques are used to remove the solvent from the system to avoid inhibition at further stages of bioethanol production and the recovered solvent should be recycled to decrease the cost of operation(Zhao et al. 2017). Low molecular weight solvents are preferred over high molecular weight solvents for economic reasons. Using nonvolatile organic compounds is considered safe since volatile solvents are flammable. 


\subsubsection{Ionic liquids}

Ionic liquids (ILs) are salts composed of large organic cations and small inorganic anions that exists as liquids (at room temperatures) are employed as solvents for the pretreatment of lignocellulosic biomass. By adjusting the anion and alkyl constituents of the cation the properties of solvents can be varied(Vitz et al. 2009). Non-flammability, low vapor pressures, chemical and thermal stability and the ability to remain as a liquid in wide range of temperature are the unique properties of ionic liquid. ILs are also known as green solvents since it does not form toxic gases. ILs form hydrogen bond between the non-hydrated chloride ions of the IL and sugar hydroxyl protons thus carbohydrates and lignin get dissolved simultaneously by ILs. Development of energy efficient recycling methods for ILs is a requirement for large scale application (Swatloski et al. 2002).

\subsubsection{Hydrogen peroxide-acetic acid pretreatment (HPAC)}

Pretreatment of lignocellulosic biomass by mixture of equal volume of hydrogen peroxide and acetic acid at $80^{\circ} \mathrm{C}$ for 2 hours. The composition of cellulose, hemicellulose and lignin recovered after HPAC treatment is $74 \%, 20 \%$ and $0.9 \%$ respectively. It results in high removal of lignin from lignocellulosic cell walls and considered as more effective in increasing enzymatic digestibility when compared to organosolv pretreatment(Wi et al. 2015).

\subsubsection{Physical-chemical methods}

\subsubsection{Steam explosion}

Steam explosion is a hydrothermal pretreatment in which the lignocellulose biomass is subjected to pressurized steam and depressurized immediately. It is considered as an important physical-chemical pretreatment method that employs high pressure saturated steam which results in autohydrolysis reactions and converts hemicellulose and lignin to soluble oligomers(Hamelinck et al. 2005). Formation of acetic acid from acetyl groups and action of water as acid at high temperature results in auto hydrolysis. It is the combined effect of mechanical forces and autohydrolysis of acetyl groups in hemicellulose. Steam explosion pretreatment increases cellulose crystallinity by promoting crystallization of amorphous structure, easy hydrolyzation of hemicellulose and progresses delignification. Moisture content of raw materials, residence time, chip size, temperature and moisture content are the factors that affect steam explosion. Hardwood such as oak and maple and agricultural wastes can be pre-treated by physical-chemical methods in a cost-effective manner but it is not much efficient for softwoods(Balat et al. 2008).

\subsubsection{Liquid hot water ( $L H W$ )}

Instead of steam, liquid hot water (LHW) is used to solubilize hemicellulose in such a way to make cellulose more accessible and to prevent inhibitor formation. During pretreatment by LHW method, the $\mathrm{pH}$ should be maintained between 4 and 7 , which minimizes the formation of monosaccharides and other degradation products, which may act as inhibitors in fermentation process. Advantage of using LHW is that the solubilized hemicellulose and lignin are present in low concentration, due to higher water input. Risk on degradation products like furfural and precipitation of lignin is reduced since they are present in lower concentration. LHW pretreatment had increased the yield of enzymatic hydrolysis from 2 to 5 -fold (Mosier et al. 2005). Thermo hydrolysis or Liquid Hot Water (LHW) pre-treatment method resulted in high recovery rates of pentoses and prevents inhibitor formation (Ogier et al. 1999).

\subsubsection{Ammonia fiber explosion (AFEX)}

Ammonia Fiber Explosion (AFEX) process is type of physicalchemical pre-treatment method, which is similar to steam explosion but yields are lower (Sun and Cheng 2002). In this pretreatment method, the biomass is subjected to liquid ammonia at raucous conditions such as high temperature and pressure and sudden decompression, which results in fast saccharificaiton. $1-2 \mathrm{~kg}$ of ammonia is used to treat $1 \mathrm{~kg}$ of biomass at a temperature of $363 \mathrm{~K}$ for $30 \mathrm{~min}$ (Mosier 2005). Treatment temperature, residence time, ammonia loading, water loading, pressure and number of treatment are the parameters that are to be considered for effective treatment of lignocellulose. Ammonia pretreatment yields 6-fold increase in enzymatic hydrolysis and 2.5 -fold increase in ethanol yield.

\subsubsection{Wet oxidation}

Wet oxidation uses oxygen as oxidizing agent for treating lignocelluloses. Pretreatment of wheat straw by wet oxidation method results in polymers whereas in case of steam explosion or acid hydrolysis it produces monomers which may act as inhibitors in further processing steps (Banerjee et al. 2009). Phenolic monomers further undergo degradation and resulted in carboxylic acids during wet oxidation. Also, other inhibitors such as furfural or hydroxymethyl furfural are produced in low concentration but causes loss in hemicellulose content (Ahring et a1. 1999).

\subsubsection{5 $\mathrm{CO}_{2}$ explosion}

Pretreatment of lignocellulose biomass by $\mathrm{CO}_{2}$ explosion method is carried out with carbon dioxide at high pressure and temperature $\left(200^{\circ} \mathrm{C}\right)$. Treatment with $\mathrm{CO}_{2}$ makes the liquid to act as acid and leads to hemicellulose hydrolysis. Glucose yield from bagasse increases from 50 $-70 \%$ when treated with supercritical carbon dioxide (Hamelinck et al. 2005).

\subsubsection{SPORL treatment}

To overcome the recalcitrant nature of lignocellulose, sulfite pretreatment can be carried out in two steps. First, hemicellulose and lignin fractions are removed by treating with calcium or magnesium sulfite followed by reduction in size using mechanical disk miller. Amount of furfural and HMF decreases with increasing bisulfite, it is attributed to the fact that $\mathrm{pH}$ will be acidic at high concentration of bisulfite, which leads to reduced sugar decomposition (Zhu et al. 2009). Due to its efficiency, and simplicity, SPORL has become more popular pretreatment method. Application of SPORL at large scale requires large amount of water for post pretreatment washing and high cost of chemicals for recovery adds to the operational cost (Zhang et al. 2013).

\subsubsection{Biological methods}

Biological pre-treatment occurs at mild environmental conditions and energy requirement is less when compared to other methods. But, most of the biological processes are slow, which limits its application at industries. Many white-rot fungi can degrade lignin and have been utilized for ligninases production and lignocellulose degradation. The variability in the content of lignin and hemicellulose is considered as one of the main problems in pre-treatment. Many factors such as biomass source (crop) harvesting method, age of crop are the reasons for the variability in lignocellulosic content of biomass. This implies that there are no generic methods available for the pre-treatment of different feedstocks (Claassen et al. 1999). The prospectus directive for biomass generation is to alter plant structure that simplifies the pre-treatment methods that are to be occurred at mild operating conditions or using enzymatic method or using genetically engineered crops with high carbohydrate content.

\subsection{Hydrolysis techniques}

Hydrolysis converts the lignocellulosic material containing the carbohydrate polymers, cellulose and hemicellulose to simple sugars before fermentation. These simple sugars are utilized during fermentation process.

\subsubsection{Chemical hydrolysis}

In chemical hydrolysis, chemicals act on lignocellulosic materials at a specific temperature for a specific time and yields sugar monomers from cellulose and hemicelluloses polymers

\subsubsection{Dilute acid hydrolysis}

Dilute acid hydrolysis uses $1 \% \mathrm{H}_{2} \mathrm{SO}_{4}$ in conversion of cellulose biomass to bioethanol. This method has a limitation that the recovery efficiency is around $50 \%$.

\subsubsection{Concentrated acid hydrolysis}

In concentrated acid hydrolysis, $10-30 \%$ concentrated acid is used and it has a minimal sugar degradation with final yield approaching $100 \%$ However, hydrolysis causes environment and corrosion problems. Acid consumption and recovery results in increased cost of the process, bringing an economic barrier (Balat 2011).

\subsubsection{Enzymatic hydrolysis}

Hydrolysis is considered as the crucial step in the production of bioethanol where carbohydrates are converted to simple monomers. When compared to acid hydrolysis, hydrolysis by enzymes requires less energy and can be operated at mild environment conditions (Ferreira et al. 2009). Low cost, less toxic and low corrosion compared to acid or alkaline pretreatment and no formation of inhibitory by-products makes it more beneficial. Cellulase and hemicellulase are the enzymes employed in hydrolysis to cleave the bonds of cellulose and hemicellulose (Kumar 
and Wyman 2009).

\subsubsection{Enzymatic hydrolysis of cellulose}

Degradation of cellulose can be accomplished by cellulase enzyme, which consists of exoglucanases, endoglucanases and â-glucosidase. Cellulase enzyme occur naturally in many microorganisms - Bacillus, Clostridium, Erwinia, Thermonospora, Microbispora, Bacteriodes, Streptomyces and fungi such as Trichoderma, Fusarium, Penicilliumm, Schizophillum sp. The optimum temperature and $\mathrm{pH}$ of cellulase is $40-50{ }^{\circ} \mathrm{C}$ and $4-5$ respectively.

Endoglucanases hydrolyze 1,4- glucosidic bonds of cellulose chains which produces new chain ends whereas exoglucanases cleave the chains of cellulose precisely at the ends to release soluble glucose; and glucosidases hydrolyze glucose to avoid cellobiose inhibition. Variation in number of cellulose end chain generated by the action of endoglucanase and consumption by glucosidase and cellulose accessibility affects cellulose hydrolysis (Xiao et al. 2004). Recent research has been focused to improve the yield and rate of enzymatic hydrolysis to enhance the activity. Crystallinity and molecular structure of cellulose, degree of swelling and surface area of cellulose fiber are the factors that affect rate of hydrolysis. Limitation in using cellulase is that rates are reduced due to product inhibition.

\subsubsection{Enzymatic hydrolysis of hemicelluloses}

Degradation of xylans require multiple enzymes such as endoxylanase, exoxylanase, $\alpha$-xylosidase, arabinofuranosidase, glucoronisidase, acetyl and xylan esterase. The main chains of xylans are attacked by endoxylanase and $\alpha$-xylosidase hydrolyzes xylooligosaccharides to xylose (Banerjee et al. 2010). Arabinose and methyl glucouronic acid substituents are removed by the action of arabinofuranosidase and glucuronidase respectively. Acetyl groups on xylose moieties are hydrolyzed by acetyl esterases. Xylan does not form crystalline structures so substrate accessibility will be more when compared to cellulose hydrolysis (Taherzadeh and Karimi 2008).

\subsection{Lignocellulosic hydrolysates detoxification}

During pre-treatment and hydrolysis of lignocellulosic biomass a large number of compounds are formed. These by-products apart from sugar monomers could inhibit the subsequent fermentation. Hydrolysis of the carbohydrate polymers results in generation of organic acids and sugar acids esterified to hemicellulose in various forms such as acetic, formic, glucuronic and galacturonic hemicellulose. Hydrolysis also results in solubilised phenolic derivatives. Degradation of soluble sugars results in generation of inhibitors such as furfural and hydroxymethyl furfural and lignin results in generation of cinnamaldehyde, p-hydroxybenzaldehyde, syringaldehyde as by products which acts as inhibitors. Inhibitors are also generated as a consequence of metal ions corrosion (Lynd 1996; Palmqvist and Hahn-Hägerdal 2000a).

In order to avoid the effect of inhibitors on fermentation process, the hydrolysate needs to be detoxified. Physical, chemical and biological methods of detoxification are used, but the degree of neutralization of the inhibitors generated varies among these methods and cannot be compared directly (Palmqvist and Hahn-Hägerdal 2000b). Furthermore, in biological method, the microorganisms employed for fermentation, have different tolerance level to inhibitors, which would also influence the detoxification process.

\subsubsection{Chemical methods for detoxification}

Phenolic compounds and furaldehydes generated by dilute acid hydrolysis are mainly separated by alkali treatment which leads to great improvement in fermentability (Persson et al. 2002). Over liming with calcium hydroxide or ammonia resulted in a better removal of inhibitors than treatment with sodium or potassium hydroxide, but the reason behind this still remain as a mystery. Different chemical detoxification methods have been proposed which includes lime based neutralization along with activated carbon addition followed by filtration to remove acetic acid. Filtration with molecular sieves to remove furfural, soluble lignin and acetic acid partially; vapor stripping to separate volatile inhibitors (Olsson and Hahn-Hägerdal 1996). Post neutralization, apart from adsorption using activated carbon, diatomite, bentonite and zeolite are also used (Yu 2003).

\subsubsection{Biological methods for detoxification}

A biofilm reactor is proposed as an alternative method for detoxification of dilute solutions from pyrolysis (Khiyami et al. 2005). The biofilm reactor is generated by immobilizing the mixed culture of aerobic bacterial cells on a plastic support. The productivity of the process is related to the rate of dilution in continuous systems where inhibitors diminish the growth rate. A control of fed-batch cultivation for in situ detoxification of spruce and birch hydrolyzates was developed with the help of on-line feedback data (Taherzadeh 1999). Through this strategy, need for detoxification treatment by converting the inhibitors using the same yeast cells was removed, which results in 10 times increase in maximal specific productivity. Metabolic engineering and genetic modifications are done to develop inhibitor-tolerant strains of microorganisms. Due to the lack of information about the mechanisms of interactions among inhibitors, inhibitor resistance is unclear (Belkacemi et al. 1997). Inhibitory substances and the mechanism of inhibition is unclear and further research has to be done to understand these hurdles.

\subsection{Fermentation of lignocellulose hydrolysate for production of bioethanol}

\subsubsection{Separate hydrolysis and fermentation (SHF)}

Separate hydrolysis and Fermentation (SHF) is a process where enzyme hydrolysis and fermentation are done separately (Wingren et al. 2008). SHF has several advantages in terms of processing. Each step can be processed at its optimal operating conditions and interaction between steps can be minimized. Enzyme hydrolysis can be done at higher temperatures for increased performance and fermentation can be operated at moderate or optimum temperatures. Due to the long process period, SHF is prone to chance of contamination and ethanol yield is minimized by product inhibition (Sánchez and Cardona 2008).

\subsubsection{Simultaneous saccharification and fermentation (SSF)}

SSF is a combined process in which hydrolysis and fermentation occurs as single processing step in one vessel. SSF is a better approach for increasing the rate of biomass to ethanol conversion (Lin and Tanaka 2006). SSF is more advantageous than SHF, by resulting in higher yield of ethanol and requires lower amounts of enzyme because end-product inhibition from cellobiose and glucose formed during enzymatic hydrolysis is mitigated by the yeast fermentation (Balat et al. 2008) and the number of reactors required is also reduced which results in low production costs. Usage of SSF in industrial scale is limited, because of the low cellulose hydrolysis rate and also the microorganisms utilised are less capable of consuming hydrolysed mixture of pentoses and hexoses. In order to trounce these limitations, enzymes that are operable at wide $\mathrm{pH}$ and temperature range should be employed for hydrolysis and the fermenting microbes should have an inherent ability to ferment the mixture of C5 and C6 sugars.

\section{Challenges in research to improve bioethanol production}

The major research challenges in $2 \mathrm{G}$ bioethanol production is to improve the hydrolysis by enzymatic process by employing efficient enzymes. In order to extend the enzymatic hydrolysis of feedstock, it is important to reduce the production cost of enzymes and to introduce a novel technology for high solid handling. The central focus of research is to develop robust fermenting microorganisms, which should tolerate inhibitors and ferment simple sugars in the concentrated hydrolysate to achieve high productivity, yield and ethanol concentration. Next major challenge is to extend the integration of process to reduce the number of steps in the process and energy demand and to re-use the process streams to reduce the use of fresh water and to decrease the amount of waste discharge (Hahn-Hägerdal et al. 2006).

\section{Strategies and research on bioethanol production in Brazil}

The Brazilian system of agroenergy is reckoned as one of the most energy effectual system. The current Brazilian energy system has evolved through years by various strategies and technological advancements.In Brazil currently more than $80 \%$ of vehicles are running with bioethanol which started as an initiative in 1970s, to substitute gasoline with alternate fuel for political and economic reasons. Sugarcane is used as feedstock for ethanol production, because of its adaptation to soil and weather conditions and could cause conflict in food production. Hence, technological and agricultural studies were strengthened in Brazil eventually ensuring energy security. The major advantage of bioethanol production from sugarcane bagasse is the use of residue, which usually rejected as waste is utilized in $10 \%$ of the total production (Soccol et al. 2010).

Brazil government initiated PróAlcool, a national program of alcohol in 1975 when energy supply became a main precedenceto promote ethanol as an socially, economically and environmentally substitute fuel. PróAlcool remained as a solution to the oil crisis as well as the fluctuating sugar prices during 1970s. 
In the first phase, $20 \%$ of anhydrous alcohol was mixed to gasoline for energy consumption and the production stayed restricted to $600,000 \mathrm{~L} /$ year as there was no firm commitment and production of alcohol was seen as a compensation for cut down in sugar cost. In phase two (19801983), the Brazilian government subsidized the expansion of sugarcane cultivation and industrial investment in distilleries and mills. Only alcoholfuelled cars were indigenously produced by the automobile factories. This phase had seen the end of gasoline industries.

In 1989, the production of alcohol in Brazil reached 11.7 billion liters, all over the country. It was reported that more than 4.5 million cars consumed only alcohol as fuel and the other 9.5 billion by a mixture of alcohol-gasoline (Puppim de Oliveira 2002a). A report from the Ministry of Mines and Energy, stated that the ethanol production in Brazil was 25 billion liters in 2008, and they exported 5.16 billion liters which was $45.7 \%$ higher than 2007 and more than twofold the exports of gasoline manufactured by major oil company in 2007 (IBGE, 2009). According to the report the bio ethanol production resulted in saving of of US\$976 million by reduction in diesel import and additional revenue generation by export of 2.8 billion liters bio ethanol to United States.Currently there are 448 bioethanol production units across Brazil with an annual ethanol production of 27 billion liters in 2009 and prediction of 105 billion liters by 2025 .

\subsection{Research in Brazil to enhance bioethanol production}

CTC -Centro de Tecnologia Canavieira (The Sugarcane Technology Center), Ridesa group, and Centro de Cana, the Cane Center from the Agronomic Institute of Campinas (IAC) have developed technology to improve sugarcane yield.The Brazilian National Institute of Science and Technology (NIST-Bioethanol) program, focuses on five different areas and are embodied by five Research Centers: (1) Center of Sugarcane Breeding; (2) Center of Plant Physiology and Cell Biology; (3) Center of Gene Expression and Transformation; (4) Center of Fungi Prospection for Glycohydrolase Production; and (5) Center of Enzyme Characterization and Process Engineering. The main aim of the centers is to pursue research on sugarcane to acquire carbohydrates, that are fermentable, from the cell wall of sugarcane (Soccol et al. 2010). They focus on understanding the structure of lignocellulosic part of sugarcane and its gene expression pattern in order to exploit them for degrading their own cell wall for subsequent hydrolysis. Also,the focus is to identify plant materials with increased susceptibility to hydrolysis. The search for microorganisms with ability to hydrolyze the walls and the enzymes responsible for degradation and genes from both sugarcaneand microorganisms is also carried out (Puppim de Oliveira 2002b).

\section{Companies producing bioethanol form lignocellulosic materials}

World wide, there are many companies involved in the production of bioethanol at commercial scale using lignocellulosic biomass. St1, Finland launched ethanol producing plants namely Etanolix ${ }^{\circledR}$, Biolonix ${ }^{\circledR}$, Cellulonix ${ }^{\circledR}$, which produces $99.8 \%$ of ethanol from wastes and process residues as transportation fuel. Etanolix plant showed a turnover of 5 million liters per year. Poet, Scotland produces 60 million gallons of ethanol per year from corn. Green Plains Inc., Omaha, US and Green field ethanol Inc., Canada produces bioethanol from agricultural and municipal wastes respectively. Some of the worldwide companies producing bioethanol, raw materials used for production and its turn over per year were tabulated in Table 4.

\section{Strategies and approach by Government of India}

The Government of India has undertaken some strategies to promote bioethanol production. The main focus is to exploit waste and degraded forest and non-forest lands for farming of shrubs and non-edible oil seeds producing trees for production of biofuels. Molasses, a by-product of sugar industry serves as the major source of raw material for bioethanol production. The second generation of technologies is based on non-food feedstocks hence the issue of fuel vs. food is irrelevant in Indian context.

In order to provide the feedstock for bioethanol,farmers, cultivators, landless labourers will be encouraged to undertake plantations. Cooperatives and self-help groups will be encouraged to take up contract farming. Plantations of non-edible oil seeds for bio-ethanol production will be supported through a Minimum Support Price. Promoting biofuels and its application in different sector will be supported by suitable financial and fiscal measures.

Research, development and demonstration will be supported to cover all aspects from feedstock production and biofuels processing for various end-use applications. Thrust will also be given to development of second generation biofuels and other new feedstocks for production of bio-diesel and bio-ethanol.

\subsection{Implementation of Ethanol Blending Programme (EBP)}

The Standing Committee on Petroleum \& Natural Gas presented the Seventh Report on "Ethanol Blended Petrol \& Bio Diesel Policy". During 2001, pilot projects on Ethanol Blended Petrol started at 3 locations i.e. at Miraj, Manmad (Maharashtra) and Aonla/Bareilly in Uttar Pradesh. The Government of India decided to launch Ethanol Blended Petrol (EBP) Programme in January, 2003 for supply of 5\% ethanol blended Petrol. Subsequent to this, Ethanol Blended Petrol programme was launched in January, 2003 in 9 States i.e. Maharashtra, Gujarat, Goa, Uttar Pradesh, Haryana, Punjab, Tamil Nadu, Karnataka, Andhra Pradesh and 4 Union Territories (UTs). The Ministry of Petroleum \& Natural Gas (MoP\&NG) vide its notification on September, 2006 regulated the Oil Marketing Companies (OMCs) to sell 5\% Ethanol Blended Petrol subject to commercial viability as per Bureau of Indian Standards specifications in notified 20 States and 4 UTs with effect from 1st November, 2006. OMCs have contracted to buy only 10.56 crore gallons of ethanol through various tenders floated since July 2016, around half of their demand of 41.21 croregallons to meet the official blending targets. Even after a decade of proposing the ethanol blending programme, the country's inability to meet the target of blending $5 \%$ ethanol with petrol in almost all states and $10 \%$ in six bio-fuel producing states is due to inadequate supplies. Not only the delay in finalization of tenders but several other barriers in implementing the ethanol blending programme have come to the fore which includes, mandatory requirement of various excise permits, levies imposed by different states on the inter-state movement of ethanol and fixed prices of ethanol for supplies even beyond 500 kilometer that adds up to transportation costs. The country could achieve only $1.4 \%$ ethanol blending with petrol in the last financial year, even lower than the 2013-14 level of $2 \%$. Only 60 crore gallons of ethanol is available in the country whereas the annual demand of ethanol is about 121.52 crore gallons in 2016for varied purposes. Government sources reported, at least 68.6 crore gallons is required per year to meet $10 \%$ of ethanol blending in gasoline. The requirement of ethanol in chemical industries and distilleries is high and competing with transportation requirement accounting to 21.12 crore gallons and about 31.70 crore gallons respectively.

Table 4.Worldwide bioethanol manufacturing companies

\begin{tabular}{|l|l|l|}
\hline Name of the company & Aim & Turn over \\
\hline $\begin{array}{l}\text { St1, Finland } \\
\text { Etanolix®, Biolonix } \\
\text { Cellulonix }\end{array}$ & $\begin{array}{l}\text { Bioethanol for transportation from } \\
\text { waste and process residues }\end{array}$ & $\begin{array}{l}99.8 \% \text { ethanol } \\
1.32 \text { million gallons per year from Etanolix }{ }^{\circledR} \text { plant }\end{array}$ \\
\hline Poet, Scotland & Bioethanol from corn & 60 million gallons per year \\
\hline $\begin{array}{l}\text { Green Plains Inc. } \\
\text { American Company } \\
\text { (Omaha, US) }\end{array}$ & $\begin{array}{l}\text { Ethanol production from corn, wheat } \\
\text { and sorghum, agricultural waste } \\
\text { products, beverage wastes and paper wastes }\end{array}$ & $\begin{array}{l}1.5 \text { billion gallons per year } \\
\text { from } 17 \text { plants }\end{array}$ \\
\hline $\begin{array}{l}\text { Green Field Ethanol Inc. } \\
\text { Canada }\end{array}$ & $\begin{array}{l}\text { Biofuels made from agricultural, } \\
\text { ford municipal waste (cellulosic ethanol) }\end{array}$ & $\begin{array}{l}173 \text { million gallons per year, of which } 40 \text { million gallons } \\
\text { and industrial and beverage grade alcohol }\end{array}$ \\
\hline
\end{tabular}


Bioethanol manufacturing capacity of Indian state distilleries including private sector and co-operative sector distilleries attached with sugar mills and standalone distilleries was depicted in Fig.4. Total of 161 distilleries, 79 private sector distilleries, 49 co-operative sector distilleries attached with sugar mills and 33 stand-alone distilleries yield around 2215500 kilo liters per annum as total contribution from different Indian states, with major producing state as Maharashtra followed by Uttar Pradesh.

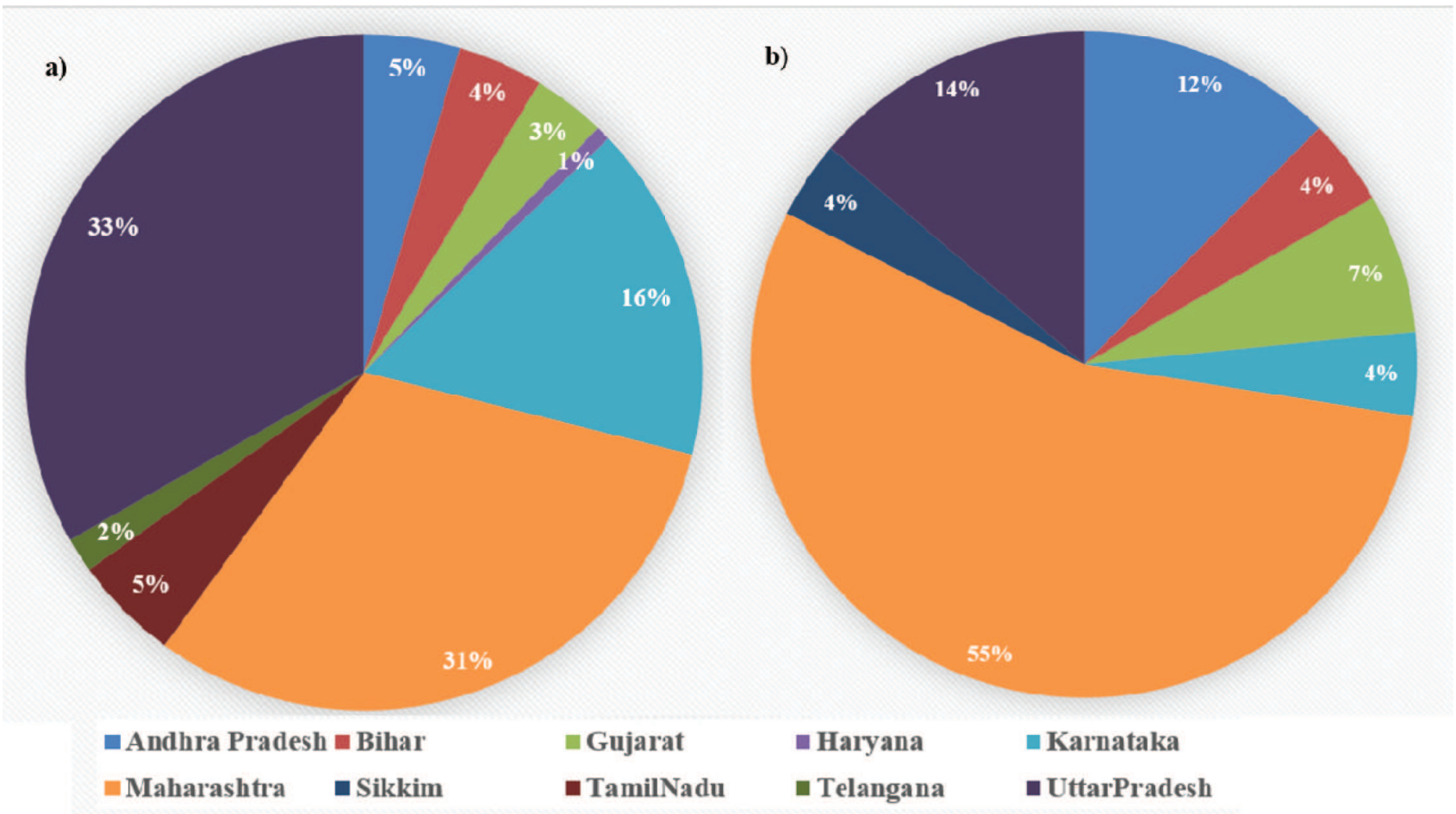

Figure 4Bioethanol manufacturing capacity of Indian states in Kilo liter per annuma) Private sector and co-operative sector distilleries attached with sugar mills b) Standalone distilleries

\subsection{Procurement of ethanol}

In order to advance the availability of ethanol and encourage ethanol blending, the Government has taken following steps:

- The Government has fixed the delivered price of ethanol and the procedure of procurement of ethanol under the EBP has been simplified to streamline the entire ethanol supply chain

- Ethanol produced from other non-food feedstocks in addition to molasses, like cellulosic and lignocellulosic materials have been allowed to be procured.

- Excise duty has been waived on ethanol supplies to OMCs for EBP by sugar mills during 2015-16.

\subsection{Interventions and enabling mechanisms}

Plantations of trees producing non-edible oilseeds will be cultivated on Government or wasteland, degraded land in forest and nonforest areas. Through the Minimum Support Price mechanism proposed in the Policy, contract farming on private wasteland could also be taken up. Over 400 species of trees bearing non-edible oilseeds are available in the country. Depending on their techno-economic viability for production of biofuels, the potential of all the species will be exploited.

To extend a mechanism for utilization of oilseeds for production of biodiesel by the processing units, a Statutory Minimum Price (SMP) mechanism will be examined for sugarcane procurement. Employment will be provided by National Rural Employment Guarantee Programme (NREGP) for planting trees and shrub to produce nonedible oilseeds. (http://mnre.gov.in/file-manager/UserFiles/biofuel_policy.pdf)

\section{Conclusion}

The important aspect by deploying bioethanol as transportation fuel is its benefit to the environment. Lignocellulosic biomass serves as an inexpensive and abundant feedstock, to produce bioethanol from renewable and sustainable resources as fuel at sensible costs. Conversion of lignocellulosic materials to bioethanol by acid hydrolysis and successive fermentation by microorganisms. The hindrances in conversion technology are processing of biomass, proper and cost-effective pretreatment methods to produce monomers that are fermentable by depolymerizing the complex polymers - cellulose and hemicellulose. The challenges involved in fermentation operation of bioethanol production are co-fermentation of pentose and hexose and to use genetically engineered microbial strains that are thermally stable and tolerant to inhibitors. The implementation of bioethanol blending programme can be helpful in development of rural economics with sustainable agricultural practices and conscious use of biomass feedstock for ethanol production.

\section{References}

Ahring BK, Licht D, Schmidt AS, et al (1999) Production of ethanol from wet oxidised wheat straw by Thermoanaerobacter mathranii. Bioresour Technol 68:3-9 . doi: $10.1016 /$ S0960-8524(98)00077-7

Balat M (2011) Production of bioethanol from lignocellulosic materials via the biochemical pathway: A review. Energy Convers Manag 52:858-875 . doi $10.1016 /$ j.enconman.2010.08.013

Balat M, Balat H, Öz C (2008) Progress in bioethanol processing. Prog Energy Combust Sci 34:551-573 . doi: 10.1016/j.pecs.2007.11.001

Banerjee S, Mudliar S, Sen R, et al (2010) Commercializing lignocellulosic bioethanol: technology bottlenecks and possible remedies. Biofuels Bioprod Biorefining 4:7793 . doi: $10.1002 /$ bbb. 188

Banerjee S, Sen R, Pandey RA, et al (2009) Evaluation of wet air oxidation as a pretreatment strategy for bioethanol production from rice husk and process optimization. Biomass Bioenergy 33:1680-1686 . doi: 10.1016/j.biombioe.2009.09.001

Belkacemi K, Turcotte G, Savoie P, Chornet E (1997) Ethanol Production from Enzymatic Hydrolyzates of Cellulosic Fines and Hemicellulose-Rich Liquors Derived from Aqueous/Steam Fractionation of Forages. Ind Eng Chem Res 36:4572-4580 . doi: 10.1021/ie970105j

Cardona CA, Quintero JA, Paz IC (2010) Production of bioethanol from sugarcane bagasse: Status and perspectives. Bioresour Technol 101:4754-4766 . doi: 10.1016/j.biortech.2009.10.097

Claassen PAM, van Lier JB, Lopez Contreras AM, et al (1999) Utilisation of biomass for the supply of energy carriers. Appl Microbiol Biotechnol 52:741-755 . doi: $10.1007 / \mathrm{s} 002530051586$

Demirbas A (2006) Hazardous Emissions, Global Climate Change and Environmental Precautions. Energy Sources Part B Econ Plan Policy 1:75-84 . doi: 10.1080/ 009083190881472

Demirbas MF, Bozbas K, Balat M (2004) Carbon Dioxide Emission Trends and Environmental Problems in Turkey. Energy Explor Exploit 22:355-365 . doi $10.1260 / 0144598043026464$ 
Dias De Oliveira ME, Vaughan BE, Rykiel EJ (2005) Ethanol as Fuel: Energy, Carbon Dioxide Balances, and Ecological Footprint. BioScience 55:593 . doi: 10.1641/ 0006-3568(2005)055[0593:EAFECD]2.0.CO;2

Ferreira S, Duarte AP, Ribeiro MHL, et al (2009) Response surface optimization of enzymatic hydrolysis of Cistus ladanifer and Cytisus striatus for bioethanol production. Biochem Eng J 45:192-200 . doi: 10.1016/j.bej.2009.03.012

Ghosh P, Ghose TK (2003) Bioethanol in India: recent past and emerging future. Adv Biochem Eng Biotechnol 85:1-27

Govindaswamy S, Vane LM (2007) Kinetics of growth and ethanol production on different carbon substrates using genetically engineered xylose-fermenting yeast. Bioresour Technol 98:677-685 . doi: 10.1016/j.biortech.2006.02.012

Hahn-Hägerdal B, Galbe M, Gorwa-Grauslund MF, et al (2006) Bio-ethanol - the fuel of tomorrow from the residues of today. Trends Biotechnol 24:549-556 . doi: 10.1016/ j.tibtech.2006.10.004

Hamelinck CN, Hooijdonk G van, Faaij AP (2005) Ethanol from lignocellulosic biomass: techno-economic performance in short-, middle- and long-term. Biomass Bioenergy 28:384-410 . doi: 10.1016/j.biombioe.2004.09.002

Hu Z, Wen Z (2008) Enhancing enzymatic digestibility of switchgrass by microwaveassisted alkali pretreatment. Biochem Eng J 38:369-378 . doi: 10.1016/ j.bej.2007.08.001

Intanakul P, Krairiksh M, Kitchaiya P (2003) Enhancement of Enzymatic Hydrolysis of Lignocellulosic Wastes by Microwave Pretreatment Under Atmospheric Pressure. J Wood Chem Technol 23:217-225 . doi: 10.1081/WCT-120021926

Khiyami MA, Pometto AL, Brown RC (2005) Detoxification of Corn Stover and Corn Starch Pyrolysis Liquors by Ligninolytic Enzymes of Phanerochaete chrysosporium. J Agric Food Chem 53:2969-2977 . doi: 10.1021/jf048223m

Kumar P, Barrett DM, Delwiche MJ, Stroeve P (2009) Methods for Pretreatment of Lignocellulosic Biomass for Efficient Hydrolysis and Biofuel Production. Ind Eng Chem Res 48:3713-3729 . doi: 10.1021/ie801542g

Kumar R, Wyman CE (2009) Effects of cellulase and xylanase enzymes on the deconstruction of solids from pretreatment of poplar by leading technologies. Biotechnol Prog 25:302-314 . doi: 10.1002/btpr.102

Lin Y, Tanaka S (2006) Ethanol fermentation from biomass resources: current state and prospects. Appl Microbiol Biotechnol 69:627-642 . doi: 10.1007/s00253-0050229-x

Lokhorst A, Wildenborg T (2005) Introduction on CO Geological Storage Classification of Storage Options. Oil Gas Sci Technol 60:513-515 . doi: 10.2516/ ogst:2005033

Lynd LR (1996) OVERVIEW AND EVALUATION OF FUEL ETHANOL FROM CELLULOSIC BIOMASS: Technology, Economics, the Environment, and Policy. Annu Rev Energy Environ 21:403-465 . doi: 10.1146/annurev.energy.21.1.403

Millett MA, Baker AJ, Satter LD (1976) Physical and chemical pretreatments for enhancing cellulose saccharification. Biotechnol Bioeng Symp 125-153

Mosier N (2005) Features of promising technologies for pretreatment of lignocellulosic biomass. Bioresour Technol 96:673-686 . doi: 10.1016/j.biortech.2004.06.025

Mosier N, Hendrickson R, Ho N, et al (2005) Optimization of pH controlled liquid hot water pretreatment of corn stover. Bioresour Technol 96:1986-1993 . doi: 10.1016/ j.biortech.2005.01.013

Ogier JC, Leygue JP, Ballerini D, et al (1999) Production d'éthanol a partir de biomasse lignocellulosique. Oil Gas Sci Technol 54:67-94 . doi: 10.2516/ogst:1999004

Olsson L, Hahn-Hägerdal B (1996) Fermentation of lignocellulosic hydrolysates for ethanol production. Enzyme Microb Technol 18:312-331 . doi: 10.1016/01410229(95)00157-3

Palmqvist E, Hahn-Hägerdal B (2000a) Fermentation of lignocellulosic hydrolysates. II: inhibitors and mechanisms of inhibition. Bioresour Technol 74:25-33 . doi: 10.1016/S0960-8524(99)00161-3

Palmqvist E, Hahn-Hägerdal B (2000b) Fermentation of lignocellulosic hydrolysates. I: inhibition and detoxification. Bioresour Technol 74:17-24 . doi: 10.1016/S09608524(99)00160-1

Pandey A (ed) (2009) Handbook of plant-based biofuels. CRC Press, Boca Raton

Pandey A, Soccol CR, Nigam P, Soccol VT (2000) Biotechnological potential of agroindustrial residues. I: sugarcane bagasse. Bioresour Technol 74:69-80 . doi: 10.1016/S0960-8524(99)00142-X

Pereira S, Maehara L, Machado C, Farinas C (2015) 2G ethanol from the whole sugarcane lignocellulosic biomass. Biotechnol Biofuels 8:44 . doi: 10.1186/s13068-0150224-0

Pereira SC, Maehara L, Machado CMM, Farinas CS (2016) Physical-chemicalmorphological characterization of the whole sugarcane lignocellulosic biomass used for $2 \mathrm{G}$ ethanol production by spectroscopy and microscopy techniques. Renew Energy 87:607-617 . doi: 10.1016/j.renene.2015.10.054

Persson P, Andersson J, Gorton L, et al (2002) Effect of Different Forms of Alkali Treatment on Specific Fermentation Inhibitors and on the Fermentability of Lignocellulose Hydrolysates for Production of Fuel Ethanol. J Agric Food Chem 50:5318-5325 doi: $10.1021 / \mathrm{jf} 0255650$

Puppim de Oliveira J. (2002a) The policymaking process for creating competitive assets for the use of biomass energy: the Brazilian alcohol programme. Renew Sustain Energy Rev 6:129-140 . doi: 10.1016/S1364-0321(01)00014-4

Puppim de Oliveira J. (2002b) The policymaking process for creating competitive assets for the use of biomass energy: the Brazilian alcohol programme. Renew Sustain Energy Rev 6:129-140 . doi: 10.1016/S1364-0321(01)00014-4

Saha BC, Iten LB, Cotta MA, Wu YV (2005) Dilute acid pretreatment, enzymatic saccharification and fermentation of wheat straw to ethanol. Process Biochem 40:3693-3700 . doi: 10.1016/j.procbio.2005.04.006

Saini JK, Saini R, Tewari L (2015) Lignocellulosic agriculture wastes as biomass feedstocks for second-generation bioethanol production: concepts and recent developments. 3 Biotech 5:337-353 . doi: 10.1007/s13205-014-0246-5

Sánchez ÓJ, Cardona CA (2008) Trends in biotechnological production of fuel ethanol from different feedstocks. Bioresour Technol 99:5270-5295 . doi: 10.1016/ j.biortech.2007.11.013

Sarkar N, Ghosh SK, Bannerjee S, Aikat K (2012) Bioethanol production from agricultural wastes: An overview. Renew Energy 37:19-27 . doi: 10.1016/ j.renene.2011.06.045

Soccol CR, Vandenberghe LP de S, Medeiros ABP, et al (2010) Bioethanol from lignocelluloses: Status and perspectives in Brazil. Bioresour Technol 101:48204825 . doi: 10.1016/j.biortech.2009.11.067

Sun R, Lawther JM, Banks WB (1995) Influence of alkaline pre-treatments on the cell wall components of wheat straw. Ind Crops Prod 4:127-145 . doi: 10.1016/09266690(95)00025-8

Sun Y, Cheng J (2002) Hydrolysis of lignocellulosic materials for ethanol production: a review. Bioresour Technol 83:1-11 . doi: 10.1016/S0960-8524(01)00212-7

Swatloski RP, Spear SK, Holbrey JD, Rogers RD (2002) Dissolution of Cellose with Ionic Liquids. J Am Chem Soc 124:4974-4975 . doi: 10.1021/ja025790m

Taherzadeh MJ (1999) Ethanol from lignocellulose: physiological effects of inhibitors and fermentation strategies. Göteborg

Taherzadeh MJ, Karimi K (2008) Pretreatment of Lignocellulosic Wastes to Improve Ethanol and Biogas Production: A Review. Int J Mol Sci 9:1621-1651 . doi: $10.3390 /$ ijms 9091621

Talebnia F, Karakashev D, Angelidaki I (2010) Production of bioethanol from wheat straw: An overview on pretreatment, hydrolysis and fermentation. Bioresour Technol 101:4744-4753 . doi: 10.1016/j.biortech.2009.11.080

Vitz J, Erdmenger T, Haensch C, Schubert US (2009) Extended dissolution studies of cellulose in imidazolium based ionic liquids. Green Chem 11:417 . doi: 10.1039/ b818061j

Wi SG, Cho EJ, Lee D-S, et al (2015) Lignocellulose conversion for biofuel: a new pretreatment greatly improves downstream biocatalytic hydrolysis of various lignocellulosic materials. Biotechnol Biofuels 8: . doi: 10.1186/s13068-015-04194

Williams PT, Onwudili J (2006) Subcritical and Supercritical Water Gasification of Cellulose, Starch, Glucose, and Biomass Waste. Energy Fuels 20:1259-1265 . doi: 10.1021/ef0503055

Wingren A, Galbe M.Zacchi G (2008) Techno-Economic Evaluation of Producing Ethanol from Softwood: Comparison of SSF and SHF and Identification of Bottlenecks. Biotechnol Prog 19:1109-1117 . doi: 10.1021/bp0340180

Xiao Z, Zhang X, Gregg DJ, Saddler JN (2004) Effects of Sugar Inhibition on Cellulases and â-Glucosidase During Enzymatic Hydrolysis of Softwood Substrates. Appl Biochem Biotechnol 115:1115-1126 . doi: 10.1385/ABAB:115:1-3:1115

Yu Z (2003) Pretreatments of cellulose pyrolysate for ethanol production by Saccharomyces cerevisiae, Pichia sp. YZ-1 and Zymomonas mobilis. Biomass Bioenergy 24:257-262 . doi: 10.1016/S0961-9534(02)00147-2

Zhang DS, Yang Q, Zhu JY, Pan XJ (2013) Sulfite (SPORL) pretreatment of switchgrass for enzymatic saccharification. Bioresour Technol 129:127-134 . doi: 10.1016/ j.biortech.2012.11.031

Zhao X, Cheng K, Liu D (2009) Organosolv pretreatment of lignocellulosic biomass for enzymatic hydrolysis. Appl Microbiol Biotechnol 82:815-827 . doi: 10.1007/ s00253-009-1883-1

Zhao X, Li S, Wu R, Liu D (2017) Organosolv fractionating pre-treatment of lignocellulosic biomass for efficient enzymatic saccharification: chemistry, kinetics, and substrate structures: Organosolv fractionating pretreatment for efficient enzymatic saccharification. Biofuels Bioprod Biorefining 11:567-590 . doi: 10.1002/bbb. 1768

Zhu JY, Pan XJ, Wang GS, Gleisner R (2009) Sulfite pretreatment (SPORL) for robust enzymatic saccharification of spruce and red pine. Bioresour Technol 100:24112418 . doi: $10.1016 /$ j.biortech.2008.10.057

http://mnre.gov.in/file-manager/UserFiles/biofuel_policy.pdf; last accessed on: 29 Aug, 2017.

www.afdc.energy./gov/data/ last accessed on: 29 Aug, 2017

http://www.financialexpress.com/market/commodities/state-levies-red-tape-hamperethanol-blending-programme/62322/last accessed on: 29 Aug, 2017.

http://timesofindia.indiatimes.com/business/india-business/Government-working-onnew-ethanol-policy-to-boost-production/articleshow/50582861.cmslast accessed on: 29 Aug, 2017.

http://wds.iea.org/wds/pdf/WEDBES_Documentation.pdflast accessed on: 29 Aug, 2017.

http://www.indiansugar.com/PDFS/List-ethanol_producers-2015-16.pdflast accessed on: 29 Aug, 2017.

http://ppac.org.in/content/147_1_ConsumptionPetroleum.aspxlast accessed on: 29 Aug, 2017. 